\title{
CHARLES WATERTON (1782-1865): CURARE AND A CANADIAN NATIONAL PARK
}

\author{
J.R. Maltby
}

INTRODUCTION

THIS YEAR MARKS the fortieth anniversary of the first intravenous use of curare by Griffith and Johnson in Montreal to produce muscle relaxation during surgery. ${ }^{1}$ That milestone in anaesthesia is one in which all Canadian anaesthetists take pride. Less well known, in the long history of curare, is the contribution of Charles Waterton, the squire of Walton Hall, Yorkshire, in the north of England. Well over a century before curare was used clinically Waterton obtained the drug from South American Indians and took it back to England, where he played a part in demonstrating that curarised animals could be kept alive by artificial ventilation until its effects wore off. $\mathrm{He}$ and others believed that the combination of curare and artificial ventilation might be the treatment of choice for tetanus and hydrophobia. Waterton's book "Wanderings in South America" was first published in 1825. In it he describes not only the preparation and use of curare by the Macusi Indians, but also several experiments and observations he made with the drug. Today curare is still obtained from the wild South American plant Chondodendron tomentosum. Crude preparation is carried out by the Indians who gather it and further purification takes place in the laboratory. ${ }^{2}$

Each year tens of thousands of tourists visit Waterton Lakes National Park in Southern Alberta. Very few realise how or why the Park is so named. Within the Park Administration little interest is taken in Waterton, much more emphasis being placed on Thomas Blakiston who surveyed this area for the Palliser Expedition in the late 1850's. However, it was Blakiston who changed the name of Kootenay Lakes to Waterton Lakes and in this paper the reason is given as to why he so honoured Charles Waterton.

The year 1982 marks the bicentenary of the birth of Charles Waterton and also the fiftieth anniversary of the dedication of the WatertonGlacier International Peace Park. It is therefore

J.R. Maltby, M.A., M.B., F.F.A.R.C.S., F.R.C.P.(C), Department of Anaesthesia, Foothills Hospital, Calgary, Alberta T2N 2 T9.

Can. Anaesth. Soc. J., vol. 29, no. 3, May 1982 an appropriate time to review the life and works of this eccentric English squire.

\section{Waterton the MaN}

Charles Waterton was born on the 3rd of June 1782 , at Walton Hall near Wakefield in northem England. He received his early schooling at home and, when he was nine years old, was sent to a Catholic boarding school. Already a keen tree-climber and birds' nester, he was repeatedly in trouble with the priests. His telling of these episodes shows us something of his eccentricity and also his sense of humour. On one occasion when he was raiding the school hen-coops for eggs and the headmaster's spaniel attacked him, his response was to knock it head-over-heels with a half-brick; unfortunately the headmaster was watching from a window and Waterton was duly punished. ${ }^{3}$ Another time, after being caught birds' nesting, he was disciplined by one of the priests who apparently hoped to eliminate the devil from him and also his love of natural science but "whilst he (the priest) was treating me to the unwelcome application of the birchrod, I flew at the calf of his leg, and made him remember the sharpness of my teeth". ${ }^{4}$

At the age of fourteen Waterton moved to the newly founded Jesuit school, Stonyhurst College, in Lancashire. Here the priests recognised that there was no real evil in him, just high spirits and a love of nature. Using common sense psychology ahead of its time they appointed him "rat-catcher, fox-taker, foumart-killer and crossbow-charger at the time when the young rooks were fledged", thus giving him a legitimate reason for being out of bounds on his nature studies. He was very happy, so much so that for many years towards the end of his long life he always returned to his old school for Christmas.

After leaving Stonyhurst he spent a few years at home and travelling in Europe. In 1804 he left England to manage the estates in Demerara (now Guyana) which his father had recently purchased. This he did, sometimes in absentia, until 1812 when he gave up management of the estates 
to set off on the first of his famous wanderings. "The chief objects in view, were to collect a quantity of the strongest Wourali* poison; and to reach the inland frontier fort of Portugese Guiana."5

Waterton's reason for wishing to obtain curare was not simply curiosity. Although there was the belief that curare might be effective in the treatment of tetanus and hydrophobia by stopping the muscular spasms, Waterton's primary reason is contained in a letter to the mayor of Nottingham in $1839^{\circ}$ (Figure 1). In this he recounts details of a meeting, many years earlier, with Sir Joseph Banks, President of the Royal Society 1778-1820, who accepted that curare would kill birds and small animals but doubted whether it would be fatal to large animals or man. Waterton accepted the challenge saying that, some day or other, he would go in quest of the poison and bring him back a true account of it. It is probably for this reason that his earliest report refers to the effect of curare on an ox. This is contained in a letter ${ }^{7}$ he sent to Stonyhurst College in January 1813 before he returned to England from Demerara. This was twelve years before the first publication of his "Wanderings in South America".

“... Having long had a desire to rove thro' the immense wilds of Guayana I left the town of Stabroekt on the 26th of April (1812), in order to procure some of the strongest Indian poison and to reach the inland military frontier post of Portuguese Guayana. I proceeded up the Demerara in a canoe with six savages for about 400 miles and then crossed overland to the Essequibo, from which river I passed into the Apoura-Poura. From the banks of this river I had seven days march by land, thr' swamps and forests $\&$ over mountains. I then got into the river Pirarara, from that into the Tacaton, from the Tacaton to the Maon, from that into the Branco where I found Fort St. Joachim. I had tough work of it on account of the periodic range, and intervals of intense heat. I collected a considerable quantity of the famous vegetable poison and tried it on an ox $960 \mathrm{lbs}$ weight. I had no idea it was so strong and fatal. I narrowly watched all the symptoms in the ox and saw him die ..... I have also about 150 of the most rare and beautiful birds and fine blowpipes for the poisoned arrows.

Chas. Waterton"

Addressed to the Reverend Charles Wright, Stonyhurst College.

In addition to his researches into curare,

* Curare.

*Now Georgetown.
Waterton collected numerous specimens of animals and birds which he took back to England. He became an expert taxidermist, achieving results far superior to those of his contemporaries. His collection of wildlife specimens eventually was given to Stonyhurst College and in the early 1970 's was transferred to Wakefield Museum, a few miles from Walton Hall. Not only did he collect and preserve dead specimens, he also established the world's first bird sanctuary. ${ }^{8}$ In fact he preceded Audubon, the great American ornithologist, as an advocate of birdprotection. He created this sanctuary at Walton Hall between 1821 and 1826 by enclosing the two hundred and fifty-nine acre estate with a six foot high wall. Before this time there had been menageries and volaries to preserve certain types of game but nothing for the protection of native wild birds.

Several biographies of Charles Waterton have been published, the most recent one in $1976,{ }^{3}$ which record examples of his rather unorthodox behaviour. Even his marriage was unusual; at the late age of forty-seven he married Ann Edmondstone, the seventeen year old daughter of an old friend, who was still a school girl at a convent in Belgium. He married her at 0400 hours on the 11 th May 1829 , she having spent the previous night in the school dormitory. Just less than a year later Ann died three weeks after giving birth to their son. Despite numerous illnesses and accidents oyer the years, some natural, others due to his own carelessness or stupidity, Waterton lived to the ripe old age of eighty three. He died, two days after falling on a narrow plank bridge on his estate, on 27th May 1865 and was buried at Walton Hall between two large oak trees.

Waterton only once allowed his portrait to be painted (Figure 2). This was in 1824 when he visited the United States and became friendly with the artist, Charles Willson Peale, in Philadelphia. Waterton's genius in taxidermy is well illustrated in the portrait which includes a stuffed bird looking up at him and the stuffed head of a tiger cat looking outwards. This painting is now in the National Portrait Gallery in London, England.

\section{Curare}

As he described in his letter to Stonyhurst from Demerara, Waterton travelled up the Demerara River, did a portage across to the River Essequibo, and went on foot through the Kanuku 


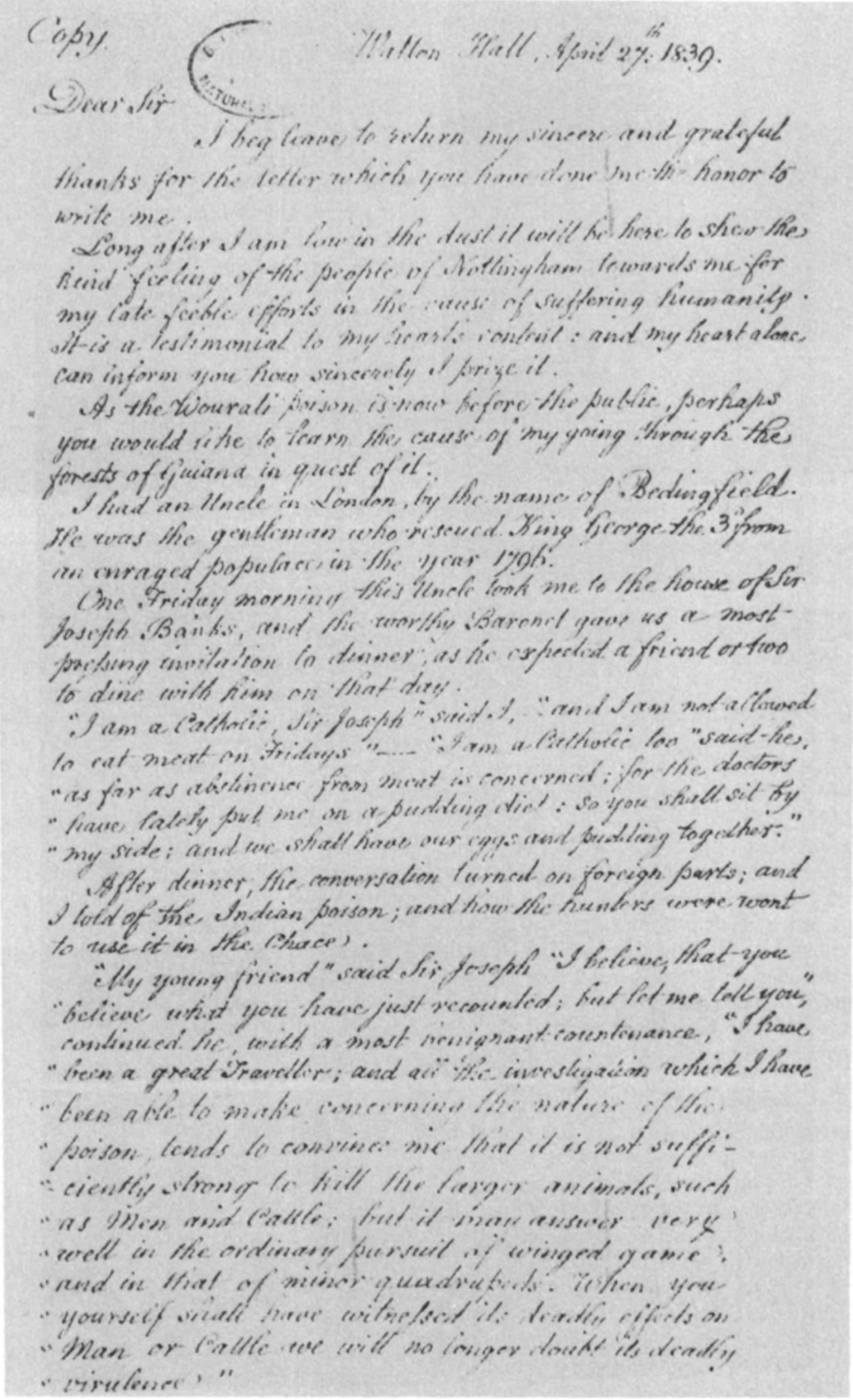

FIGURE 1 Letter from Charles Waterton to the Mayor of Nottingham. (See Text). From British Museum of Natural History. 


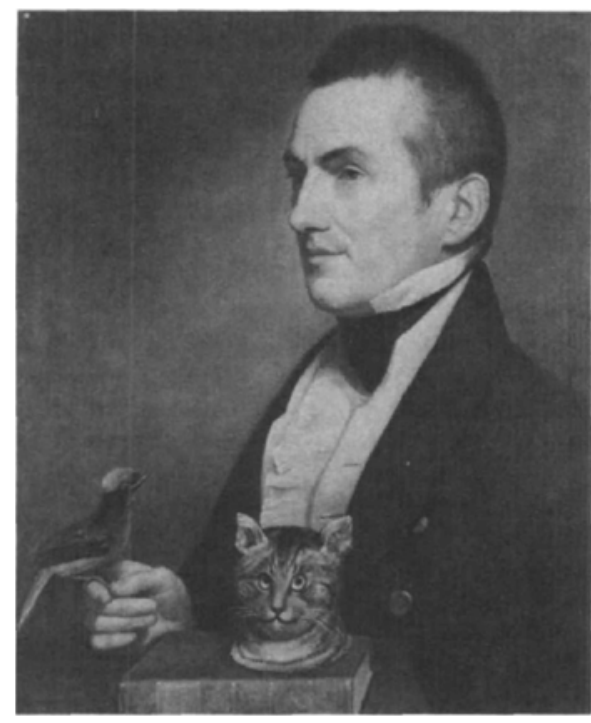

Figure 2 Portrait of Charles Waterton by Charles Willson Peale, 1824. (National Portrait Gallery, London, England.)

Mountains to reach a tributary of the Rio Branco which eventually drains into the Amazon. It was in the upper reaches of the Essequibo that he found the Macusi Indians with their potent curare.

Before reaching the Macusi Indians he obtained a small quantity of curare from an Indian who claimed to have killed several wild hogs and two tapirs with it. Waterton's description of his first experiment is clear and detailed. "Its strength was provided on a middle-sized dog. He was wounded in the thigh, in order that there might be no possibility of touching a vital part. In three or four minutes he began to be affected, smelt at every little thing on the ground about him, and looked wistfully down at the wounded part. Soon after this he staggered, laid himself down, and never rose more. He barked once, though not as if in pain. His voice was low and weak; and in a second attempt it quite failed him. He now put his head betwixt his fore legs, and raising it slowly again, he fell over on his side. His eyes immediately became fixed, and though his extremities every now and then shot convulsively, he never showed the least desire to raise up his head. His heart fluttered much from the time he laid down, and at intervals beat very strong; then stopped for a moment or two; then beat again, and continued faintly beating several minutes, after every other part of his body seemed dead. In a quarter of an hour after he had received the poison he was quite motionless. $" 5$

To kill animals the Indians used bows and arrows while for birds they used the blow pipe. The blow-pipe, made from a very long reed, was from ten to eleven feet long and the arrows nine to ten inches long. About an inch of the pointed end was coated with poison. The quiver of arrows, its case and three diamond shaped arrows tips, shown in Figure 3 , belonged to Waterton and are now on display in the Wakefield Museum.

"The photograph shows a quiver of arrows and a bottle with three spikes of Wourali poison. The former fits into the case (roughly $209.5 \mathrm{~cm}$ long and $9.0 \mathrm{~cm}$ wide at the base) which is made of basket work coated with a hard wax-like substance. It has a cap made of skin with a label, written, I think, by Waterton himself: 'Quiver with poisoned arrows for the blow pipe from Guiana, 1812. See the Wanderings, 1st journey.' The arrows are straight pieces of wood (around $205.5 \mathrm{~cm}$ long and less than $2 \mathrm{~mm}$ in diameter) with a sharp point at one end which is coated with a dark grey substance. They are bound together into two pieces of string and then rolled up around a central stick. The wheel at one end appears to be to protect the user from the poisoned tips.

"The bottle is empty, but has three diamond shaped arrows tips set into the cork. Again, these arrows are coated. The bottle has a label written by J.G. Wood 'Spikes of Wourall Poison given to me by Mr. Waterton June 20, 1839 J.G.W."

Waterton wrote that, ${ }^{16}$ Though the wourali poison is used by all the South A merican savages betwixt the Amazons and the Oroonoque, still this tribe makes it stronger than any of the rest.

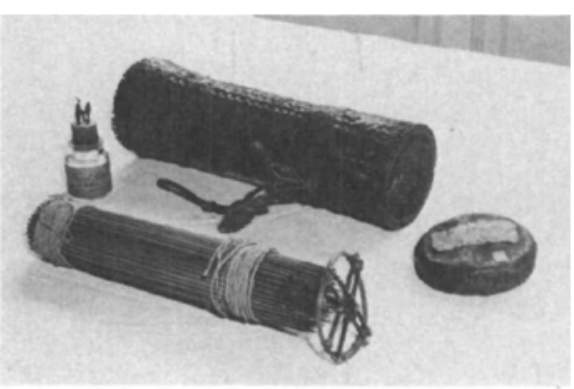

FIGURE 3 "A quiver of arrows and a bottle with three spikes of Wourali poison" (See text). (Wakefield Art Gallery and Museums.) 
The Indians in the vicinity of the Rio Negro are aware of this, and came to the Macoushi country to purchase it."

He found the Macusi Indians, who were the makers of the most potent curare, and may have been allowed to watch its manufacture. This would be a special privilege because its preparation was partly ritualistic and attended by taboos. Waterton was remarkably clear-sighted in sorting out those ingredients and processes which were essential from those which merely represented superstition. "A day or two before the Macoushi Indian prepares his poison he goes into the forest in quest of the ingredients. A vine grows in these wilds, which is called wourali. It is from this that the poison takes its name, and it is the same principle ingredient." This was a significant observation since he also records that the Indians added large black ants and small red ants, snakes' fangs and pepper - even though he believed these were superfluous. "When he has procured enough of these, he digs up a root of a very bitter taste, ties them together, and then looks about for two kinds of bulbous plants, which contain a green and glutinous juice ... he scrapes the wourali vine and bitter root into thin shavings, and puts them into a kind of colander made of leaves: this he holds over a earthen pot and pours water on the shavings: the liquor which comes through has the appearance of coffee. When a sufficient quantity has been procured, the shavings are thrown aside. He then bruises the bulbous stalks and squeezes a proportionate quantity of their juice through his hands into the pot ... It is then placed on a slow fire, and as it boils, more of the juice of the wourali is added, according as it may be found necessary, and the scum is taken off with leaf: it remains on the fire till reduced to a thick syrup of a deep brown colour. As soon as it has arrived at this state, a few arrows are poisoned with it, to try its strength ..." Ritualistic trappings included the exclusion of females in case the Yabahou or evil spirit harmed them, the fasting of the poisonmaker on the morning of, and throughout, the preparation and the abandonment of the shed in which boiling had taken place.

Waterton goes on to describe the killing of various birds and animals, noting that paralysis usually commenced about three minutes after injection of the curare. His descriptions are precise and much more picturesque than those we now read in scientific journals. Consider the following: "Having procured a healthy wellgrown fowl, a short piece of a poisoned blow- pipe arrow was broken off, and run up into its thigh, as near as possible, betwixt the skin and flesh, in order that it might not be incommoded by the wound. For the first minute it walked about, but walked very slowly, and did not appear the least agitated. During the second minute it stood still, and began to peck the ground; and ere half another had elapsed, it frequently opened and shut its mouth. The tail now dropped, and the wings almost touched the ground. By the termination of the third minute, it had sat down, scarce able to support its head, which nodded, and then recovered itself, and then nodded again, lower and lower every time, like that of a weary traveller slumbering in an erect position; the eyes alternatively open and shut. The fourth minute brought on convulsions, and life and the fifth terminated together." Waterton also drew certain conclusions from his observations. One was that curare, although fatal when injected into an animal, did not poison the meat for human consumption and therefore was inactive when taken by mouth. He observed that the effects of curare were doserelated and that it was because this was not taken into account that birds died in five minutes while an ox took twenty-five. It was Waterton's opinion that, since the Indians did not carry an antidote in case of accidental self-injection, they did not know of one. He made the interesting observation though, that "It is supposed by some, that wind, introduced into the lungs by means of a small pair of bellows would revive the poisoned patient, provided the operation be continued for a sufficient length of time."

He returned to England with a severe tertian ague (malaria) and it was three years before he was fully recovered. In 1814, however, he helped to prove that artificial respiration will indeed keep a curarised animal alive. Three years earlier Sir Benjamin Brodie had curarised a rabbit and, after its breathing had stopped but with its heart still beating, performed a tracheostomy and inflated its lungs thirty six times a minute. Although the rabbit died, Brodie was convinced that artificial respiration was the answer. And so in 1814, Brodie, assisted by Professor Sewell of the Veterinary College and with Waterton supplying the curare, carried out the famous experiment. Waterton described the sequence of events, "A she-ass received the wourali poison in the shoulder and died apparently in ten minutes. An incision was then made in its windpipe, and through it the lungs were inflated for two hours, with a pair of bellows. 
Suspended animation retumed; but the inflating being discontinued, she sunk once more in apparent death. The artificial respiration was immediately recommenced and continued without intermission for two hours. This saved the ass from final dissolution; she rose up and walked about; she seemed neither in agitation nor pain."

This was really the end of Waterton's contributions concerning curare although his interest in it continued for many years. In 1838 he wrote to George Ord, an ornithologist whom he had met in Philadelphia through the artist Charles Willson Peale. "Our philosophers suppose that the Wourali poison will cure patients labouring under hydrophobia and lockjaw. We have already had proof positive that it will cure lockjaw and $\mathbf{I}$ think it not improbable that we shall soon have an opportunity of trying its sanatory powers in hydrophobia. About three weeks ago, in the neighbourhood of Nottingham, six men were bitten by a mad dog. They were sent to the General Infirmary at Nottingham and the bitten parts were cut out. The patients are now at the seaside, for the benefit of bathing. The house surgeon has written to me and ardently begged some wourali poison, requesting at the same time that I will send him instructions how it ought to be used in case of need. I have answered him to say that if any of the patients shall show symptoms of decided hydrophobia and that if the attending scientific men declare the case to be quite hopeless, he must send an express and I will be with him without loss of time." 10 Such an opportunity did not occur then but it did in the following year. Inspector Phelps, a Nottingham policeman, rescued a trapped dog which then bit him. Six weeks later he became ill and developed hydrophobia. Francis Sibson, surgeon at Nottingham General Hospital, sent for Waterton, but by the time he arrived from Walton Hall with his wax-coated ball of curare, the policeman was dead. Thus was the opportunity lost for curare use in the treatment of a human disease.

Soon after this episode Sibson and Waterton repeated the 1814 donkey experiment. ${ }^{11}$ One animal was ventilated for seven hours but died three days later. A second animal needed only one hour's ventilation and survived. Since this use of curare and artifical ventilation took place in Nottingham, it is singularly appropriate that, when an Intensive Care Unit was opened at Nottingham General Hospital, it was named Waterton Ward.

\section{Waterton Lakes National Park}

Waterton Lakes National Park in Southern Alberta takes its name from the Waterton Lakes. It was opened in 1911 with an area of only 13.5 square miles, not much more than the three lakes. Three years later it was enlarged to over four hundred square miles so that the park now stretches from the Great Divide in west to the Blood Indian Reserve in the east, and from the International Boundary to the Carbondale River in the Crows Nest Pass area. The Upper Waterton Lake, shown in Figure 4, crosses the International boundary into Glacier National Park in Montana. Following a joint meeting of Rotarians from Alberta and Montana in July 1931, a petition was sent to the American and Canadian Governments requesting the creation of an International Peace Park embracing Waterton and Glacier. Both Governments agreed and the following Spring, President Herbert Hoover dedicated the Peace Park. June 18, 1982 marks the fiftieth anniversary of that event, and on that date Canada Post will issue a special commemorative stamp.

Had it not been for the Palliser Expedition, which explored western Canada from Lake Superior to the Rocky Mountains in the late 1850's, we should still have the Kootenay Lakes and, presumably, Kootenay Lakes National Park. During 1858 the main expedition split into three groups. Thomas Blakiston, an English Royal Artillery officer, led the party whose object was to report on possible routes through the Rockies north of the U.S. border and south of the existing fur trading route via Athabasca Portage and the Big Bend on the Columbia River. They crossed the mountains through the North Kootenay Pass, returning by the South Kootenay pass into what is now Southem Alberta and descended to the Kootenay Lakes, which Blakiston renamed Waterton Lakes. The Palliser Papers simply have a footnote, "Blakiston called these lovely lakes after the great naturalist, Charles Waterton."12 In somewhat different vein a popular guidebook states, "With the blithe indifference of the explorer to the customs of the country, Blakiston ignored the name Kootenay and renamed the three lakes 'Waterton', after an English naturalist, Charles Waterton."13

Waterton had nothing whatever to do with exploration in Western Canada. The only time he was in Canada was for a few days in 1824 


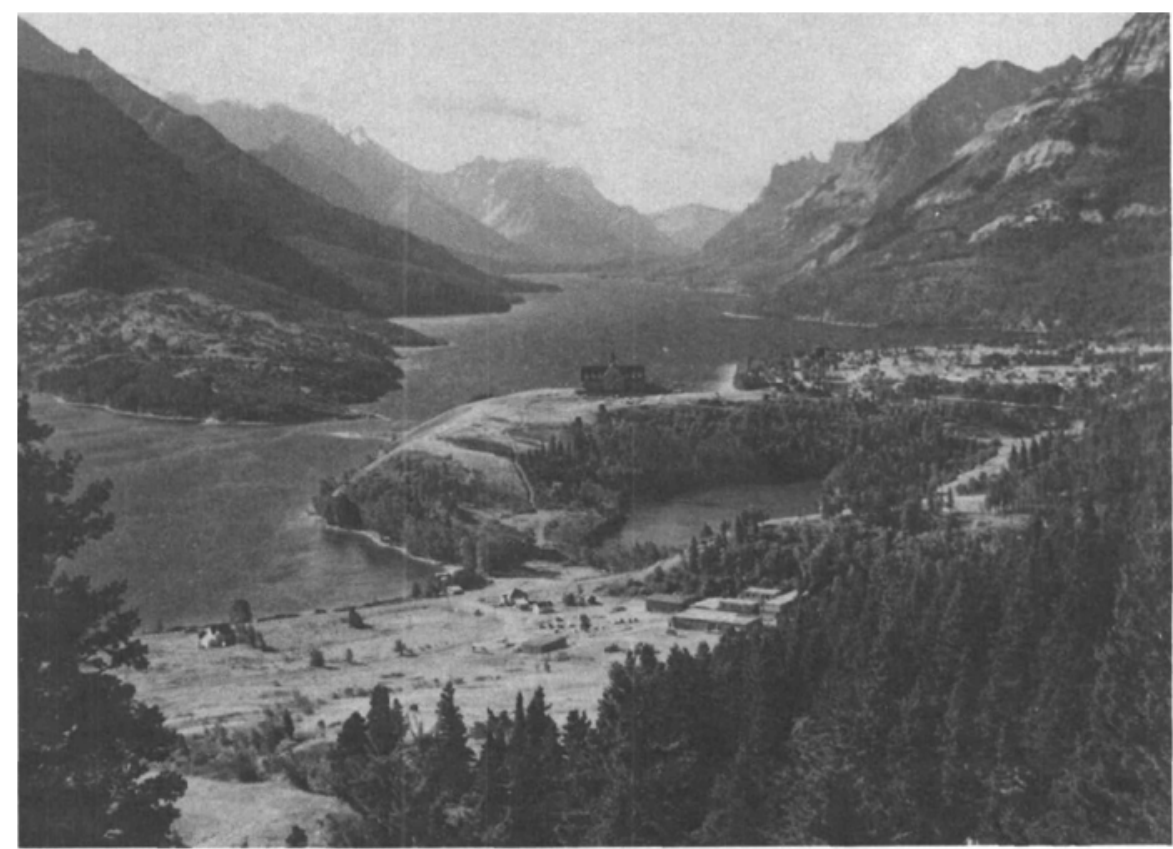

Figure 4 Waterton Lakes National Park. (Photograph by J.R. Maltby.)

when he took a short trip to Montreal and Quebec City during his visit to the eastern United States. Why then, did Blakiston choose to honour him?

While Blakiston was in Canada he had already established his interest in the study of wildlife. After completing his work with the Palliser Expedition, he went to Japan where he became a well-known ornithologist, and made an extensive collection of birds for the museum at Hakadote. He also sent bird specimens to the United States National Museum and living animals to the Zoological Society in London. He later published papers on the birds of British North America and Japan. ${ }^{14}$

During his exploration in Southern Alberta Blakiston honoured other British explorers and scientists by naming Gould's Dome after John Gould (1804-1881), ornithologist; Livingstone's Range after David Livingstone (18131873), missionary and African explorer; and Galton's Range after Sir Francis Galton (18221911), scientist, explorer and anthropologist, who was a cousin of Charles Darwin. ${ }^{1}$

Whatever Waterton's eccentricities, Blakiston must have ranked him among the top scientists and explorers of his time to have given his name to the Waterton Lakes and hence the Waterton-Glacier Intemational Peace Park of Canada and the United States.

\section{ACKNOWLEGEMENTS}

The author wishes to thank the following for their helpful information, suggestions and criticism: Rev. F.J. Tumer, Stonyhurst College Librarian; Bari M. Logan, Prosector, Royal College of Surgeons of England; and Dr. W.D.A. Smith, University of Leeds.

\section{REFERENCES}

1. Grifitih, H.R. \& Johsson, G.E. The use of curare in general anaesthesia. Anesthesiology 3: 481 (1942).

2. Burroughs Wellcome Inc. Personal Communication (1981).

3. PHELPS, G. Squire Waterton. Wakefield, England. EP Publishing Limited (1976)

4. Aldington, R. The Strange Life of Charles Waterton, London. Evans Brothers Limited (1949).

5. WaTErToN, C. Wanderings in South America, London, New York, Toronto, Oxford University Press (1973). 
6. The Richard Owen Collection - Letters. British Museum (Natural History).

7. Stonyhurst College Archives.

8. ThomAs, K.B. Curare, Its History and Usage. Great Britain. Pitman Medical Publishing Company (1963).

9. Watson G. Personal Communication (1980).

10. IRWIN, R.A. (ED.). Letters of Charles Waterton. London. Rockcliffe (1955)

11. Maltby, J.R. Francis Sibson, 1814-1876. Anaesthesia 33: 53 (1977).
12. SPRY I.M. (Ed.) The Papers of the Palliser Expedition 1857-1860. Toronto. The Champlain Society (1968).

13. Anderson, F.W. Waterton, and of Leisure. Calgary: Frontier Publishing Limited (1968)

14. LEE, G. (Ed.) Dictionary of National Biography, Vol. XXII (Supplement). London. Smith, Elder and Company (1909).

15. HaIG, B. In the Footsteps of Thomas Blakiston1858. Historic Trails Society of Alberta, Lethbridge, Alberta (1981). 